\title{
Original article \\ Characterization of fermentation liquid from mangrove leaves Avicennia marina and its inhibitory potential for bacterium causing ice- ice disease
}

\section{Karakterisasi cairan fermentasi daun mangrove Avicennia marina dan daya hambatnya terhadap bakteri penyebab penyakit ice-ice}

\author{
Samsu Adi Rahman ${ }^{1,2}$, Sukenda $^{2 *}$, Widanarni $^{2}$, Alimuddin $^{2}$, Julie Ekasari ${ }^{2}$ \\ ${ }^{1}$ Study Program of Aquaculture, Faculty of Fisheries, University of Muhammadiyah Luwuk, Luwuk, Indonesia \\ ${ }^{2}$ Department of Aquaculture, Faculty of Fisheries and Marine Sciences, IPB University, Bogor, Indonesia. \\ *Corresponding author: sukenda@ipb.ac.id
}

(Received April 18, 2019; Accepted July 10, 2019)

\begin{abstract}
Fermentation liquid from mangrove leaves Avicennia marina contains microorganisms, nutrients, and secondary metabolites. This study aimed to identify bacteria and the compounds in fermentation liquid of mangrove leaves $A$. marina and measured their inhibitory capacity against pathogenic bacteria Stenotrophomonas maltophilia which causes ice-ice disease in seaweed. Molecular analysis which aimed the 16S rRNA gene showed that the bacteria in fermentation liquid consisted of eight types of Bacillus, Bacillus subtilis MSAR-01, Bacillus megaterium MSAR02, Bacillus firmus MSAR-03, Bacillus thuringiensis MSAR-04, Bacillus subterranerus MSAR-05, Bacillus vietnamensis MSAR-06, Bacillus sp. MSAR-07, Bacillus circulans MSAR-08, with the best inhibitory power indicated by B. subtilis MSAR-01, B. vietnamensis MSAR-06, and Bacillus sp. MSAR-07. The administration of lactic acid, bacteriocin, total fermentation liquid, and supernatant as much as $15 \mu \mathrm{L}$ produce inhibition to $S$. maltophilia indicated better result than using one or a combination of several types of bacterial isolates. The inhibition of single bacterial enriched fermentation and supernatant liquids was better than bacterial combination enrichment.
\end{abstract}

Keywords: Avicennia marina, fermentation, ice-ice, mangrove

\begin{abstract}
ABSTRAK
Cairan fermentasi daun mangrove Avicennia marina mengandung mikroorganisme, nutrient, dan metabolit sekunder. Penelitian ini bertujuan untuk mengidentifikasi bakteri dan senyawa dalam cairan fermentasi daun mangrove A. marina dan mengukur daya hambatnya terhadap bakteri patogen Stenotrophomonas maltophilia penyebab penyakit ice-ice pada rumput laut. Hasil analisis molekuler dengan target gen 16S rRNA menunjukkan bahwa bakteri dalam cairan fermentasi terdiri atas delapan jenis Bacillus, yaitu Bacillus subtilis MSAR-01, Bacillus megaterium MSAR-02, Bacillus firmus MSAR-03, Bacillus thuringiensis MSAR-04, Bacillus subterranerus MSAR-05, Bacillus vietnamensis MSAR-06, Bacillus sp. MSAR-07, Bacillus circulans MSAR-08, dengan daya hambat terbaik ditunjukkan oleh B. subtilis MSAR-01, B. vietnamensis MSAR-06, dan Bacillus sp. MSAR-07. Pemberian asam laktat, bakteriosin, cairan fermentasi total, dan supernatan sebanyak $15 \mu \mathrm{L}$ menghasilkan daya hambat terhadap bakteri S. maltophilia lebih baik daripada menggunakan salah satu atau kombinasi beberapa jenis bakteri isolat. Daya hambat cairan fermentasi dan supernatan yang diperkaya bakteri tunggal lebih baik daripada pengayaan kombinasi bakteri.
\end{abstract}

Kata kunci: Avicennia marina, fermentasi, ice-ice, mangrove 


\section{INTRODUCTION}

Seaweed Kappaphycus alvarezii is fisheries main commodity. Seaweed production in 2015 reached 14.7 million tons and Indonesia's seaweed production contributed $39 \%$ of world total seaweed production (FAO, 2018). One of the obstacle in seaweed production is disease. The infectious disease in seaweed usually is iceice disease. Ice-ice is most common disease in seaweed culture since it can be very harmful and could lowered seaweed production up to $100 \%$ (Vairappan, 2006). Ice-ice disease caused by opportunistic bacteria (Egan et al., 2017; Kumar et al., 2016), is Stenotrophomonas maltophilia (Achmad et al., 2016).

Various efforts to control ice-ice disease has done by introduction to gene encoding lisozyme enzyme (Handayani et al., 2014), dismutase superoxide enzyme (Triana et al., 2016), inhibition test for mangrove leave Sonnerati alba extract (Syafitri et al., 2017), inhibition test for endophytic bacteria of mangrove leave Avicennia marina. Mangrove leaves A. marina used as indigenous microorganisms (IMO) source, is group of innate microbial consortium that inhabits the soil and the surface of all living things inside and outside (Umi \& Saria, 2006), and easily available in that environment (Kumar \& Gopal, 2015). IMO has potentiality in nitrogen fixation, increase soil fertility, phosphates solvent, and increase plant growth (Umi \& Saria, 2006), bioremediation (Kao et al., 2016; Sarkar et al., 2016; Kumar \& Gopal, 2015), and protect host from pathogenic microorganism (Kumar \& Gopal, 2015), biactivator (Mirwandono et al., 2018), increase the availability of nutrients for host (Sakimin et al., 2017; Suyanto \& Irianto, 2016), and as fermentation agent (Anyanwu et al., 2015).

Mangrove leaves contains endophytic microorganism (IMO) (Rahman et al., 2019) that has potentially used as antibacteria (Sanchez et al., 2018). The use of fermenting liquid from various source of IMO has been done to increase plant growth and soil fertility (Kumar et al., 2015), and to control pathogen in plant (Kumar \& Gopal, 2015). Fermentation liquid is commonly used to inhibit pathogenic bacteria, anti-fungal, anti-mycotoxin (Waters et al., 2015), and to increase growth (Sakimin et al., 2017). Fermentation liquid contains primer and secondary metabolite produced by lactic acid bacteria (lactic acid and bacteriocin). Lactic acid is antimicrobial substance produced by lactic acid bacteris to inhibit the growth of pathogenic microbes (Wang et al., 2015). Bacteriocin is peptide substance that synthesized by bacteria in ribosome (Hegarty et al., 2016). This two has bactericidal and bacteriostatic activity against pathogen. Therefore, this study aimed to identify bacteria and fermentation liquid compound of mangrove leaves Avicennia marina, and to test the inhibitionagainst ice-ice disease caused by $S$. maltophilia bacteria.

\section{MATERIALS AND METHOD}

\section{Pathogenic bacteria culture}

Pathogenic bacteria as causative agent of ice-ice disease $S$. maltophilia with highest pathogenicity obtained from previous study of Achmad et al. (2016). Koch's Postulates used for pathogenicity test. Bacteria isolate was cultured in sea water complex (SWC) agar medium $(0.5 \mathrm{~g}$ of bacto pepton, $0.1 \mathrm{~g}$ of yeast extract, $0.3 \mathrm{~mL}$ of glycerol, $1.5 \mathrm{~g}$ of bacto agar, $75 \mathrm{~mL}$ of sea water, dan $25 \mathrm{~mL}$ of aquades) and was incubated in $28^{\circ} \mathrm{C}$ for 24 hours. Then, it was vcultured into SWC liquid media and was homogenizedby shaker in 140 rpm for 24 hours.

\section{Fermentation of mangrove leaves Avicennia marina and bacteria identification}

Fermentation procedure was according to method of Budiyani et al. (2016) and Valli et al. (2016). Old and wet mangrove leaves was minced and added some palm sugar, sterile sea water with ratio of 1:1/4:2. The mangrove leaves were fermented in closed container without any exposure for two weeks. The fermentation liquid filtered with cheese cloth, then it put in glass bottle in $-20^{\circ} \mathrm{C}$.

Filtered fermentation liquid was isolated, then the bacteria was identified, test the inhibitionagainst disease and pythochemical compound was analyzed. As much as $0.1 \mathrm{~mL}$ of fermentation liquid was put and placed in a tube for serial dilution $\left(10^{-5}\right)$ by using sterile seawater. Afterward, $0.1 \mathrm{~mL}$ of every isolate was cultured in SWC agar medium in $28^{\circ} \mathrm{C}$ for 24 hours to obtain a pure isolate.Bacteria identification has done by molecular technology with gene target was 16S rRNA. PCR amplification used primer 63F (5'-CAG GCC TAA CAC ATG CAA GTC$3^{\prime}$ ) and 1387R (5'-GGG CGG WGT GTA CAA 
GGC-3') (Marchesi et al., 1998) with gene target of 1,300 base pair. DNA extraction was according to Presto $^{\mathrm{TM}}$ mini gDNA bacteria kit (Geneaid manufacture's Taiwan) protocol. Sequence analysis has done by sending the amplification product to $1^{\text {st }}$ BASE DNA Sequencing, Malaysia. DNA sequencing result was analyzed by using Bio Edit Software. Then, the sequence was macthed against 16S rRNA sequence database in GeneBank (http://www.ncbi.gov/ BLAST) by using basic local allignment search toolnucleotide (BLAST-N) program.

Inhibition test against lactic acid, bacteriocin, total fermentation liquid, and supernatant of bacteria caused ice-ice disease

Lactic acid compound in fermentation liquid was measured by using high performance liquid chromatography (HPLC). As much as $5 \mathrm{~mL}$ of supernatant put in a $25 \mathrm{~mL}$ measuring cup, some aquades was added into it, then the mixture was homogenized by using a sentrifuge in $7500 \mathrm{rpm}$ for three minutes. The supernatant was filtered by using $0.45 \mu \mathrm{m}$ filtration membrane in a vial then it was injected into HPLC. Afterward, the lactic acid compound can be measured (Gezginc et al., 2015). Bacteriocin raw extract compound was measured from total fermentation liquid. The supernatant was extracted twice by using $10 \%$ ammonium sulfate solvent. The extract was steamed in an evaporator to obtain thick extract then it was stored in desiccator (Badi \& Bhat, 2017). Lactic acid and bacteriocin inhibition test was done by using paper disc with diameter of 0.5 $\mathrm{cm}$ (Whatman no.4). Paper disc was put in SWC agar medium with $10^{6}$ cells $/ \mathrm{mL}$ of $S$. maltophilia inoculation. Every paper disc was dropped with lactic acid $(5,10$, and $15 \mu \mathrm{L})$ and bacteriocin $(5$, 10 , and $15 \mu \mathrm{L}$ ) then it was incubated in $28{ }^{\circ} \mathrm{C}$ for 24 hours. The dosage was according to Biswas et al. (2017). After incubation, the inhibition zone was measured and analyzed.

The total fermentation liquid was sentrifuged in $10,000 \mathrm{rpm}$ for 10 minutes and the supernatant was filtered by using $0.22 \mu \mathrm{m}$ filtration paper. The paper disc with diameter of $0.5 \mathrm{~cm}$ (Whatman no.04) was put in SWC agar medium with $10^{6}$ cells $/ \mathrm{mL}$ of $S$. maltophilia inoculation. Then, the paper disc was dropped with the total fermentation liquid and the supernatant $(5,10$, dan $15 \mu \mathrm{L})$, it was incubated in $28{ }^{\circ} \mathrm{C}$ for 24 hours. After incubation, the inhibition zone was measured and analyzed.

\section{Inhibition test of bacteria isolate of fermentation liquid}

Inhibitation test of bacteria isolate from fermentation liquid (endophyte) toward $S$. maltophilia was done by in vitro test of KirbyBauer method as in line with Achmad et al. (2016), then it was dropped by $10^{5} \mathrm{cell} / \mathrm{mL}$ of endophytic bacteria. The inhibition test result was selected on best three and it was combined with KirbyBauer method against S. maltophilia. Then, the fermentation liquid and supernatant was enriched with three endophytic bacteria with best inhibition and was enriched with the combination of three endophytic bacteria. The density of endophytic bacteria was $10^{5}$ cells/ $\mathrm{mL}$ of each. This density is considered able to suppress pathogen. As much as $100 \mu \mathrm{L}$ of bacteria isolate was put into $10 \mathrm{~mL}$ of fermentation liquid and supernatant to test the resistibility towards the combination of three endophytic bacteria. Then, the challenge test was done by dropped the liquid as much as $5 \mu \mathrm{L}$ above paper disc in $S$. maltophilia isolation. It was incubated in $28^{\circ} \mathrm{C}$ for 24 hours. The diameter was measured and analyzed.

\section{Phytochemical analysis}

Phytochemical analysis of fermentation liquid was done by qualitative method. Phytochemical compounds that was analyzed were alkaloid, saponin, tannin, phenolic, flavonoid, triterpenoid, steroid, and glycoside. It was analyzed by standard procedure.

\section{Data analysis}

Molecular and phytochemical identification data used descriptive analaysis, while inhibition of lactic acid, bacteriocin, fermentation liquid, supernatant, and inhibition of bacteria was analyzed by using ANOVA test of SPSS 20 version. In case, if it would significantly different, the test further used Tukey test.

\section{RESULTS}

\section{Isolat bakteri dari cairan fermentasi bacteria isolate of fermentation liquid}

The moleculer identification of bacteria isolate of fermentation liquid was obtained eight strain of Bacillus (Table 1). The result of BLAST showed the similarity between $16 \mathrm{~S}$ rRNA sequences from bacteria isolate with BLAST database was $99-100 \%$. This similarity showed degree of accuracy in moleculer identification of certain strain bacteria. The result showed that the sequence was in species level. 
Table 1. Bacteria isolate from fermentation liquid of mangrove A. marina leaves according to the percentage of similarity of $16 \mathrm{~S}$ rRNA gene nucleotide sequences.

\begin{tabular}{ccccc}
\hline Isolate & Bacteria & Similarity (\%) & Subject & Access number \\
\hline MSAR-01 & Bacillus subtilis strain BR4 & 100 & $1256 / 1256(100 \%)$ & KU052617.1 \\
MSAR-02 & Bacillus megaterium YC4-R4 & 100 & $1247 / 1247(100 \%)$ & CP026740.1 \\
MSAR-03 & Bacillus firmus strain PGRP4 & 99 & $1098 / 1099(99 \%)$ & MG229068.1 \\
MSAR-04 & Bacillus thuringiensis strain VKK-SL-2 & 100 & $1116 / 1116(100 \%)$ & KT714055.1 \\
MSAR-05 & Bacillus subterranerus strain FJAT-47744 & 99 & $1250 / 1252(99 \%)$ & MG651149.1 \\
MSAR-06 & Bacillus vietnamensis strain FJAT-46928 & 100 & $1086 / 1086(100 \%)$ & MG651539.1 \\
MSAR-07 & Bacillus sp. strain FJAT 47851 & 100 & $995 / 995(100 \%)$ & MG651253.1 \\
MSAR-08 & Bacillus circulans strain MD1 & 100 & $1253 / 1253(100 \%)$ & KT757520.1 \\
\hline
\end{tabular}

Table 2. Inhibition activity of lactic acid and bacteriocin against S. maltophilia

\begin{tabular}{ccc}
\hline \multirow{2}{*}{ Doses of compound } & \multicolumn{2}{c}{ Inhibition diameter $(\mathrm{mm})(\mathrm{X} \pm \mathrm{SD})$} \\
\cline { 2 - 3 } & Lactic acid & Bacteriocin \\
\hline Control (aquades $10 \mu \mathrm{L})$ & $00.00 \pm 0.00^{\mathrm{a}}$ & $00.00 \pm 0.00^{\mathrm{a}}$ \\
$5 \mu \mathrm{L}$ & $8.95 \pm 0.54^{\mathrm{b}}$ & $9.05 \pm 0.11^{\mathrm{bc}}$ \\
$10 \mu \mathrm{L}$ & $10.00 \pm 0.50^{\mathrm{cd}}$ & $10.85 \pm 0.49^{\mathrm{d}}$ \\
$15 \mu \mathrm{L}$ & $13.30 \pm 0.84^{\mathrm{e}}$ & $12.25 \pm 0.59^{\mathrm{f}}$ \\
\hline
\end{tabular}

Note: different superscript in same column and bar showed significantly different result $(\mathrm{P}<0.05)$.

Table 3. Inhibition activity of fermentation liquid and supernatant against $S$. maltophilia

\begin{tabular}{ccc}
\hline \multirow{2}{*}{ Doses of product } & \multicolumn{2}{c}{ Inhibition diameter $(\mathrm{mm})(\mathrm{X} \pm \mathrm{SD})$} \\
\cline { 2 - 3 } Control $($ aquades $10 \mu \mathrm{L})$ & Fermentation liquid & Supernatant \\
$5 \mu \mathrm{L}$ & $00.00 \pm 0.00^{\mathrm{a}}$ & $00.00 \pm 0.00^{\mathrm{a}}$ \\
$10 \mu \mathrm{L}$ & $9.55 \pm 0.33^{\mathrm{b}}$ & $9.35 \pm 0.34^{\mathrm{b}}$ \\
$15 \mu \mathrm{L}$ & $11.45 \pm 0.37^{\mathrm{c}}$ & $11.25 \pm 0.59^{\mathrm{c}}$ \\
\hline
\end{tabular}

Note: different superscript in same column and bar showed significantly different result $(\mathrm{P}<0.05)$.

Table 4. Inhibition activity of single bacteria and bacteria combination against S. maltophilia

\begin{tabular}{|c|c|}
\hline Bacteria & Inhibition diameter $(\mathrm{mm})(\mathrm{X} \pm \mathrm{SD})$ \\
\hline B. subtilis MSAR-01 & $9.50 \pm 0.11^{\mathrm{a}}$ \\
\hline B. megaterium MSAR-02 & $8.43 \pm 0.08^{\mathrm{e}}$ \\
\hline B. firmus MSAR-03 & $8.02 \pm 0.24^{\mathrm{f}}$ \\
\hline B. thuringiensis MSAR-04 & $7.76 \pm 0.12^{\mathrm{f}}$ \\
\hline B. subterranerus MSAR-05 & $8.70 \pm 0.20^{\mathrm{cd}}$ \\
\hline B. vietnamensis MSAR-06 & $9.11 \pm 0.11^{\mathrm{b}}$ \\
\hline Bacillus sp. MSAR-07 & $9.41 \pm 0.14^{\mathrm{a}}$ \\
\hline B. circulans MSAR-08 & $8.90 \pm 0.14^{\mathrm{bc}}$ \\
\hline B. subtilis MSAR-01+B. vietnamensis MSAR-06 & $8.00 \pm 0.00^{\mathrm{f}}$ \\
\hline B. subtilis MSAR-01+Bacillus sp. MSAR-07 & $8.50 \pm 0.00^{\mathrm{de}}$ \\
\hline B. vietnamensis MSAR-06+ Bacillus sp. MSAR-07 & $8.00 \pm 0.00^{\mathrm{f}}$ \\
\hline B. subtilis MSAR-01+ B. vietnamensis MSAR-06+ Bacillus sp. MSAR-07 & $8.00 \pm 0.00^{\mathrm{f}}$ \\
\hline
\end{tabular}

Note: Different superscript in same column showed significantly different result $(\mathrm{P}<0.05)$ 
Table 5. Inhibition activity of fermentation liquid and fermentation enriched with single bacteria and bacteria combination against $S$. maltophilia

\begin{tabular}{lcc}
\hline \multicolumn{1}{c}{ Enrichment } & \multicolumn{2}{c}{ Inhibition diameter $(\mathrm{mm})(\mathrm{X} \pm \mathrm{SD})$} \\
\cline { 2 - 3 } & Liquid fermentation & Supernatant \\
\hline B. subtilis MSAR-01 & $16.60 \pm 0.55^{\mathrm{a}}$ & $13.10 \pm 0.14^{\mathrm{b}}$ \\
B. vietnamensis MSAR-06 & $15.00 \pm 0.94^{\mathrm{a}}$ & $11.55 \pm 1.04^{\mathrm{bcd}}$ \\
Bacillus sp. MSAR-07 & $15.55 \pm 0.45^{\mathrm{a}}$ & $12.60 \pm 0.55^{\mathrm{bc}}$ \\
B. subtilis MSAR-01+B. vietnamensis MSAR-06 & $12.20 \pm 0.27^{\mathrm{bc}}$ & $12.65 \pm 1.14^{\mathrm{bc}}$ \\
B. subtilis MSAR-01+ Bacillus sp. MSAR-07 & $12.00 \pm 1.00^{\mathrm{bcd}}$ & $11.70 \pm 0.84^{\mathrm{bcd}}$ \\
B. vietnamensis MSAR-06+Bacillus Sp. MSAR-07 & $12.50 \pm 1.00^{\mathrm{bc}}$ & $11.00 \pm 1.00^{\mathrm{cd}}$ \\
B. subtilis MSAR-01+B. vietnamensis MSAR-06+ Bacillus & $12.80 \pm 0.76^{\mathrm{b}}$ & $10.40 \pm 0.89^{\mathrm{d}}$ \\
sp. MSAR-07 & & \\
\hline Note: Different & &
\end{tabular}

Note: Different superscript in same column showed significantly different result $(\mathrm{P}<0.05)$

Table 6. Phytochemical compound of fermentation liquid and supernatant

\begin{tabular}{|c|c|c|}
\hline \multirow{2}{*}{ Compound } & \multicolumn{2}{|c|}{ Qualitative results } \\
\hline & Fermentation liquid & Supernatant \\
\hline Alkaloid & + & + \\
\hline Saponin & + & - \\
\hline Tannin & + & + \\
\hline Phenolic & + & + \\
\hline Flavonoid & + & + \\
\hline Triterpenoids & + & - \\
\hline Steroids & - & - \\
\hline Glycoside & + & + \\
\hline
\end{tabular}

Keterangan: (+): ada, (-): tidak ada Note : (+) Existed, (-) Not existed

Inhibition of lactic acid, bacteriocin, fermentation liquid, and supernatant

By using HPLC, it was known that lactic acid content in fermentation liquid amounted $19,117.78 \mathrm{mg} / \mathrm{L}$, whereas, crude extract of bacteriocin was $2.5 \%$. Lactic acid and bacteriocin inhibition of different dose against ice-ice disease showed in Table 2.

According to inhibition test against $S$. maltophilia, highest lactic acid inhibition $(\mathrm{P}<0.05)$ showed at dose of $15 \mu \mathrm{L}(13.30 \mathrm{~mm})$, followed by dose of $10 \mu \mathrm{L}(10.00 \mathrm{~mm}), 5 \mu \mathrm{L}(8.95 \mathrm{~mm})$, and control $(0.00 \mathrm{~mm})$. Likewise, highest bacteriocin inhibition showed at dose of $15 \mu \mathrm{L}(12.25 \mathrm{~mm})$, followed by $10 \mu \mathrm{L}(10.85 \mathrm{~mm}), 5 \mu \mathrm{L}(9.05 \mathrm{~mm})$, and control $(0.00 \mathrm{~mm})$. This results showed that as the increase of treatment dose of lactic acid and bacteriocin, the inhibition activity increased. The treatment of lactic acid that showed significantly different rather than bacteriocin was dose of 15 $\mu \mathrm{L}(\mathrm{P}<0.05)$.

Inhibition activity of fermentation liquid and supernatant against $S$. maltophilia showed various value within dosage. The inhibition activity increased as the treatment of fermentation liquid and supernatant increased (Table 3 ).
The study results showed that fermentation liquid and supernatant assigned significantly different result $(\mathrm{P}<0.05)$ of inhibition activity against $S$. maltophilia. The respons between fermentation liquid and supernatant treatment with various doses was significantly different. Highest inhibition activity of fermentation liquid showed at dose of $15 \mu \mathrm{L}(15.25 \mathrm{~mm})$, followed by $10 \mu \mathrm{L}(11.45 \mathrm{~mm}), 5 \mu \mathrm{L}(9.55 \mathrm{~mm})$, and control $(0.00 \mathrm{~mm})$. Likewise, highest inhibiton activity of supernatant showed at dose of $15 \mu \mathrm{L}$ (14.15 $\mathrm{mm})$, followed by $10 \mu \mathrm{L}(11.25 \mathrm{~mm}), 5 \mu \mathrm{L}$ (9.35 $\mathrm{mm})$, and control $(0.00 \mathrm{~mm})$. Inhibition activity of fermentation liquid in all treatment was not significantly different $(\mathrm{P}>0.05)$ compare to inhibition activity of supernatant.

\section{Bacteria inhibition activity}

Single cell bacteria inhibition from fermentation liquid and combination of two or three kind of bacteria against S. maltophilia showed in Table 4, meanwhile the inhibition of fermentation liquid and supernatant enriched with bacteria showed in Table 5. The combination of bacteria by using single cell bacteria were $B$. 
subtilis MSAR-01 isolate, Bacillus sp. MSAR-07 isolate, and B. vietnamensis MSAR-06 isolate, which all of them has best inhibition activity against disease (Table 4). Then, the combination of isolate was expected to generate better inhibition activity. Yet, the result showed that inhibition activity among the combination of two or three bacteria was lower than single bacteria. Highest inhibition activity has showed by $B$. subtilis MSAR-01 isolate, followed by Bacillus sp. MSAR-07, and B. vietnamensis MSAR-06 isolate.

The results of inhibition activity from fermentation liquid and supernatant enriched with selected potential bacteria showed that every treatment could generate significantly different inhibition activity $(\mathrm{P}<0.05)$ against $S$. maltophilia, showed in Table 5.

Inhibition activity of fermentation liquid that enriched with single bacteria was better than supernatant that enriched with single bacteria (Table 5). Then, fermentation liquid enriched with single cell bacteria had higher inhibition activity than fermentation liquid and supernatant enriched with combination of two or three bacteria. Inhibition activity of fermentation liquid that combined with single bacteria did not significantly different with supernatant enriched with single bacteria. Meanwhile, supernatant combined with two kind of bacteria did not significantly different with supernatant combined with single bacteria, otherwise it did significantly with supernatant combined with three kind of bacteria, whereas the treatment of $B$. subtilis MSAR-01+B. vietnamensis MSAR-06+ Bacillus sp. MSAR-07 combined with supernatant has lower inhibition activity than it combined with fermentation liquid.

\section{Phytochemical compound}

Phytochemical screening was done to obtain bioactive compound in fermentation liquid. The result of phytochemical test indicated that fermentation liquid contains alkaloid, saponin, tannin, phenolic, flavonoid, triterpenoids, and glycoside that allegedly as antibacterial (Table 6).

\section{DISCUSSION}

Molecular identification showed that there were eight isolates from Bacillus sp species. Eight bacteria isolates were Firmicutes that are very common found in marine water. This bacteria was isolated from mangrove Avicennia marina leaves and (Rahman et al., 2019) and found abundantly in green algae Ulva and Gracilaria (Singh et al., 2015). Commonly, Bacillus sp. is lactic acid bacteria (BAL) produced several antimicrobial compound like lactic acid, alcohol, carbon dioxide, diacetyl, hydrogen peroxide, bacteriocinand other metabolic compounds (Gaggia et al., 2010). This bacteria is used as probiotic and biocontrol agent to suppress the growth of pathogenic bacteria through various mechanism, one of them is produced metabolic compound (Widanarni et al., 2015). Bacteriocin that produced by this bacteria can increase health (Woraprayote et al., 2016), has high specific target, and is effective to control the pathogen (Ansari et al., 2018).

Inhibition activity towards lactic acid and bacteriocin from fermentation liquid against $S$. maltophilia bacteria was significantly different in dosage of $15 \mu \mathrm{L}$. This difference due to different inhibition spectrum, was suspected cause by organism sensitivity in higher dosage. The ability to inhibit lactic acid and bacteriocin showed bactericidal and bacteriostatic characteristic, as higher the lactic acid and bacteriocin concentration, the inhibition ability gets higher (Table 2). This results showed that lactic acid and bacteriocin produced by fermentation liquid has extensive inhibition ability against $S$. maltophilia. It was in line with Smid and Gorris (2007) that stated organic acid produced by lactic acid bacteria has extensive inhibition spectrum against microorganism. The mechanism started with attack cell wall, cell membrane, enzyme metabolism, interfere both protein synthesis system and genetic. Identified bacteria of fermentation liquid was Gram positive bacteria with stronger inhibition ability. Then, Sandi and Salasia (2016) explained that Gram positive bacteria has smaller bacteriocin with more extensive antimicrobe spectrum than Gram negative bacteria.

Fermentation liquid showed better inhibition activity than the supernatant. Antimocrobe compound of fermentation liquid worked optimally than the supernatant (Tabel 3). This was happen due to the loss of some compound through particles sediment when sentrifuged and cell separated from its supernatant by using filter of $0.22 \mu \mathrm{m}$. Antimicrobes compound in fermentation liquid was whole antimicrobe with other particles compund therefore it worked more specific against $S$. maltophilia. Inhibition activity of fermentation liquid and supernatant of every treatment has different ability according its concentration level. The amount of inhibiton 
activity is according to its concentration level. As higher the concentration, the higher its inhibition activity. Some compounds that worked for S. maltophilia inhibition were lactic acid, bacteriocin, and other identified active compound in phytochemist test (alkaloid, saponin, tannin, phenolic, flavonoid, and glycoside) (Table 6). Sandi and Salasia (2016) stated that lactic acid bacteria produced some bioactive compounds with wider inhibition activity and spectrum against pathogen. Then, Cebrian et al. (2018) stated that bacteriocin is antimicrobe molecule with selective ability to inhibit certain bacteria species that produced bacteriocin (Ahmad et al., 2016).

Bacteria and fermentation liquid had different inhibition activity against $S$. maltophilia (Table 4). Three species of Bacillus sp. with best inhibition activity was $B$. subtilis MSAR-01, Bacillus sp. MSAR-07, and B. vietnamensis MSAR-06. This three species was potential bacteria candidate to control ice-ice disease in seaweed. This study results showed that the combination of this three potential bacteria had lower inhibition activity than single potential bacteria and enrichment of single bacteria was better that bacteria combination (Table 5). This bacteria combination was not effective yet to suppress the pathogen since every single bacteria had its own mechanism to inhibit the pathogen and their effectivity was become lower if it was combined with other species. This was in line with enrichment both of single bacteria and bacteria combination due to both bacteria synergies and antimicrobes compound in fermentation liquid and supernatant before bacteria enrichment. Faust (2018) stated that to optimize consortium performance is by right design or microorganism combination through some experiments. Cookson (1995) explained that the different inhibition activity is depend on microbes preference during biodegradation process, so did the biochemist process and specific enzymes in it.

Phytochemist compound (Table 6) from qualitative fermentation liquid contained alkaloid, saponin, tannin, phenolicm flavonoid, and glycoside, meanwhile, the supernatant had no saponin, triterpenoid, and steroid. This was caused by the compounds was degraded through particles sediment while centrifugation process and cell separation from its supernatant by using filter of $0.22 \mu \mathrm{m}$, therefore, it made lower inhibition ability of supernatant than fermentation liquid against $S$. maltophilia. Some compounds had antibacterial activity. Alkaloid explored the inhibition of bacteria quorum sensing (Rabin et al., 2015). Flavonoid, phenolic, and tannin played an important role as antioxidant source (Hamli et al., 2017). Glycoside engaged to destroy microbe cell wall by catalytic or anabolic (Rijai, 2016).

\section{CONCLUSION}

Some bacteria in fermentation liquid were eight species of Bacillus. Fermentation liquid of mangrove leaves was very potential to control iceice disease in seaweed. The enrichment of single bacteria in fermentation liquid and supernatant was worked better than single bacteria, bacteria combination, and enrichment of bacteria combination. The best enrichment bacteria of fermentation liquid was $B$. subtilis MSAR-0.

\section{REFERENCES}

Achmad M, Alimuddin A, Widyastuti U, Sukenda S, Suryanti E, Harris E. 2016. Molecular identification of new bacterial causative agent of ice-ice disease on seaweed Kappaphycus alvarezii. PeerJ Preprint 4: 1-22.

Ahmad V, Khan MS, Jamal QMS, Alzohairy MA, Al Karawi MA, Siddiqui MU. 2016. Antimicrobial potential of bacteriocins: in therapy, agriculture and food preservation. International Journal of Antimicrobial Agents 49: $1-11$.

Ansari A, Pervez S, Javed U, Abro MI, Nawaz MA, Qader SAU, Aman A. 2018. Characterization and interplay of bacteriocin and exopolysaccharide-mediated silver nanoparticles as an antibacterial agent. International Journal of Biological Macromolecules 115: 643-650.

Anyanwu CF, Ngohayon SL, Ildefonso RL, Ngohayon JL. 2015. Application of indigenous microorganisms (IMO) for bioconversion of agricultural waste. International Journal of Science and Research 4: 778-784.

Badi R, Bhat M. 2017. Isolation studies of bacteriocin producing lactic acid bacteria from raw goat milk. World Journal of Microbiology 4: 093-099.

Batara LN, Anas I, Santosa DA, Lestari Y. 2016. Aplikasi mikroorganisme lokal (MOL) diperkaya mikrob berguna pada budidaya padi system of rice intensification (SRI) organic. Jurnal Tanah dan Iklim 40: 71-78. 
Biswas K, Upadhayay S, Rapsang GF, Joshi SR. 2017. Antibacterial and synergistic activity against $\beta$-laktamase-producing nosocomial bacteria by bacteriocin of LAB isolated from lesser known traditionally fermented products of India. Hayati Journal of Biosciences 24: 87-95.

Budiyani NK, Soniari NN, Sutari NWS. 2016. Analisis kualitas mikroorganisme lokal (MOL) bonggol pisang. Agroekoteknologi Tropika 4: 63-72.

Cebrian R, Arevalo S, Rubino S, Arias-Santiago S, Rojo MD, Montalban-Lopez M, MartínezBueno M, Valdivia E, Maqueda M. 2018. Control of Propionibacterium acnes by natural antimicrobial substances: Role of the bacteriocin AS-48 and lysozyme. Scientific Reports 8: 1-11.

Cookson JT. 1995. Bioremediatian Engineering Design and Application. New York: McGraw-Hill, Inc. pp. 524.

Egan S, Kumar V, Zozaya-Valdez, Gardiner ME, Hudson J. Deshpande N, Campbell A. 2017. Breaking bad: opportunistic bacterial pathogens of seaweeds. Phycologia 5: 48-49.

FAO (Food and Agriculture Organization). 2018. The global status of seaweed production, trade and utilization. Global Research Programme 124: $1-120$.

Faust K. 2018. Microbial consortium design benefits from metabolic modeling. Trends in Biotechnology 37: 123-125.

Gaggia F, Mattarelli P, Biavati B. 2010. Review: Probiotics and prebiotics in animal feeding for safe food production. International Journal of Food Microbiology 141: S15-S28.

Gezginc Y, Topcal F, Comertpay S, Akyol I. 2015. Quantitative analysis of the lactic acid and acetaldehyde produced by Streptococcus thermophilus and Lactobacillus bulgaricus strains isolated from traditional Turkish yogurts using HPLC. Journal of Dairy Science 98: 1426-1434.

Hamli S, Kadi K, Addad D, Bouzerzour H. 2017. Phytochemical screening and radical scavenging activity of whole seed of durum wheat (Triticum durum Desf.) and barley (Hordeum vulgare L.) varieties. Jordan Journal of Biological Sciences 10: 323-327.

Handayani T, Alimuddin, Widyastuti U, Suryati E, Parenrengi A. 2014. Binary vector construction and Agrobacterium tumefaciens- mediated transformation of lysozyme gene in seaweed Kappaphycus alvarezii. Biotropia 21: 80-90.

Hegarty JW, Guinane CM, Ross RP, Hill C. 2016. Bacteriocin production: a relatively unharnessed probiotic trait ?. F1000Research 2587: 1-9.

Kao C, Lin B, Chen S, Wei S, Chen C, Yao C, Chien C. 2016. Biodegradation of trinitrotoluene (TNT) by indigenous microorganisms from TNT-contaminated soil, and their application in TNT bioremediation. Bioremediation Journal 20: 165-173.

Kumar V, Zozaya-Valdez E, Kjelleberg S, Thomas T, Egan S. 2016. Multiple opportunistic pathogens can cause a bleaching disease in the red seaweed Delisea pulchra. Environmental Microbiology 18: 3962-3975.

Kumar BL, Gopal DVRS. 2015. Effective role of indigenous microorganisms for sustainable environment. 3 Biotech 5: 867-876.

Kumar A, Bahadur I, Maurya BR, Raghuwanshi R, Meena VS, Singh DK, Dixit J. 2015. Does a plant growth promoting rhizobacteria enhance agricultural sustainability? Journal of Pure and Applied Microbiology 9: 715-724.

Mirwandono E, Sitepu E, Wahyuni TH, Hasnudi, Ginting N, Siregar GAW, Sembiring I. 2018. Nutrition quality test of fermented waste vegetables by bioactivator local microorganism (MOL) and effective microorganism (EM4). IOP Conference Series: Earth and Environmental Science 122: 012-127.

Moussa D, Konan KM, Koffi NE, MamyrbekovaBekro JA, Bekro YA. 2018. Phytochemical screening and antioxidant profile of leave decoctions of five wild edible plants from Cote d'Ivoire. Journal of Materials and Environmental Sciences 9: 724-729.

Rabin N, Zheng Y, Opoku-Temeng C, Du Yixuan, Bonsu E, Sintim HO. 2015. Agents that inhibit bacterial biofilm formation. Future Medicinal Chemistry 7: 647-671.

Rahman SA, Sukenda S, Widanarni W, Alimuddin A, Ekasari J. 2019. Isolation and identification of endophytic bacteria from mangrove leaves and evaluation of their inhibitory potential against ice-ice disease-causing bacteria. AACL Bioflux 12: 1-12. [Accepted]

Rijai L. 2016. Senyawa glikosida sebagai bahan farmasi potensial secara kinetik. Journal of Tropical Pharmacy and Chemistry 3: 213-218. 
Sanchez RG, Barrientos DS, Galindez JL. 2018. Effect of indigenous microorganism extended solution (IMO-ES) on basmati rice. International Journal of Agricultural Technology 14(7): 1871-1882.

Sakimin SZ, Azwani N, Rahim NAA, Juraimi AS, Alam MA, Aslani F. 2017. Effects of indigenous microorganism and system of rice intensification formulation on growth, physiology, nutrient uptake and rice yield. Bangladesh Journal of Botany 46: 433-438.

Sandi NA, Salasia SIO. 2016. Alternative antibiotics source symbiont of lactid acid bacteria inside stomach of honeybees (Apis mellifera and Apis dorsata) against multiresistant antibiotics pathogenic bacteria. Research Journal of Microbiology 11: 93-100.

Sarkar J, Kazy SK, Gupta A, Dutta A, Mohapatra B, Roy A, Bera P, Mitra A, Sar P. 2016. Biostimulation of indigenous microbial community for bioremediation of petroleum refinery sludge. Frontiers in Microbiology 7: $1-20$.

Singh RP, Baghel RS, Reddy CRK, Jha B. 2015. Effect of quorum sensing signals produced by seaweed-associated bacteria on carpospores liberation from Gracilaria dura. Frontiers in Plant Scince 6: 1-13.

Smid EJ, Gorris LGM. 2007. Natural antimicrobials for food preservation. In: Rahman MS (editor). Handbook of Food Preservation. $2^{\text {nd }}$ Edition. New York. CRC Press. pp 1068

Suyanto A, Irianti ATP. 2016. Efektivitas Trichoderma sp. dan mikro organisme lokal (MOL) sebagai dekomposer dalam meningkatkan kualitas pupuk organik alami dari beberapa limbah tanaman pertanian. Jurnal Agrosains 12: 1-7.

Syafitri E, Prayitno SB, Radjasa OK, Ma'ruf WF. 2017. The performance of mangrove leaf extract Sonnerati alba in combating bacterial associated with ice-ice disease of seaweed Kappaphycus alvarezii. Advanced Science Letters 23: 6413-6415.
Triana SH, Alimuddin, Widyastuti U, Suharsono, Suryati E, Parenrengi A. 2016. Improvement method of gene transfer in Kappaphycus alvarezii. Jurnal Ilmu dan Teknologi Kelautan Tropis 8: 249-258.

Umi KMS, Sariah M. 2006. Utilization of microbes for sustainable agriculture in Malaysia: current status. Bio prospecting and management of microorganisms. National Conference on Agro biodiversity conservation and sustainable utilization 27-29.

Vairappan CS. 2006. Seasonal occurrences of epiphytic algae on the commercially cultivated red alga Kappaphycus alvarezii (Solieriaceae, Gigartinales, Rhodophyta). Journal of Applied Phycology 18: 611-617.

Valli V, Danesi F, Gianotti A, Nunzio MD, Saa DLT, Bordoni A. 2016. Antioxidative and anti-inflammatory effect of in vitro digented cookies baked using different types of flours and fermentation methods. Food Research International 8: 256-262.

Wang C, Chang T, Yang H, Cui M. 2015. Antibacterial mechanism of lactic acid on physiological and morphological properties of Salmonella Enteritidis, Escherichia coli and Listeria monocytogenes. Food Control 47: 231-236.

Waters DM, Mauch A, Coffey A, Arendt EK, Zannini E. 2015. Lactic acid bacteria as a cell factory for the delivery of functional biomolecules and ingredients in cereal-based beverages: a review. Critical Reviews in Food Science and Nutrition 55: 503-520.

Widanarni, Nopitawati T, Jusadi D. 2015. Screening of probiotic bacteria candidates from gastrointestial tract of pasific white shrimp Litopenaeus vannamei and their effect on the growth performances. Research Journal of Microbiology 10: 145-157.

Woraprayote W, Malila Y, Sorapukdee S, Swetwiwathana A, Benjakul S, Visessanguan W. 2016. Bacteriocins from lactic acid bacteria and their applications in meat and meat products. Meat Science 120: 118-132. 